\title{
Perbandingan Positivitas Metode MODS, Pewarnaan ZN, dan GeneXpert untuk Mendeteksi M. tuberculosis pada Pasien Meningitis TB
}

\author{
Niken Ayu Paramitha, ${ }^{1}$ Yunia Sribudiani, ${ }^{2,3}$ Ahmad Rizal ${ }^{4,5}$ \\ ${ }^{1}$ Program Studi Pendidikan Dokter, Fakultas Kedokteran Universitas Padjadjaran Bandung, Indonesia \\ ${ }^{2}$ Departemen Ilmu Kedokteran Dasar, Divisi Biokimia dan Biologi Molekuler, Fakultas Kedokteran Universitas \\ Padjadjaran, Bandung, Indonesia, ${ }^{3}$ Pusat Studi Genetika Medis, Fakultas Kedokteran Universitas Padjadjaran, \\ Bandung, Indonesia, ${ }^{4}$ Departemen Ilmu Penyakit Saraf Fakultas Kedokteran Universitas Padjadjaran/Rumah \\ Sakit Dr. Hasan Sadikin Bandung, Indonesia, ${ }^{5}$ Pusat Studi Infeksi Klinis, Fakultas Kedokteran Universitas \\ Padjadjaran Bandung, Indonesia
}

\begin{abstract}
Abstrak
Salah satu permasalahan dalam diagnosis meningitis tuberkulosis (TB) adalah rendahnya positivitas metode yang digunakan. Berbagai metode telah dikembangkan, mulai dari metode kultur MODS (microscopic observation drug susceptibility), pewarnaan Ziehl-Neelsen (ZN), hingga GeneXpert. Penelitian ini dilakukan untuk menentukan metode diagnostik terbaik mendeteksi $M$. tuberculosis berdasar atas nilai positivitasnya. Penelitian ini merupakan observasional analitik dengan rancangan potong lintang. Data berasal dari penelitian kohort dan ReDEFINe meningitis TB di Rumah Sakit Umum Pusat Dr. Hasan Sadikin Bandung. Data diambil dari case report form pasien dengan diagnosis meningitis TB pada periode Juli 2014-Juni 2016. Kriteria inklusi penelitian ini adalah usia $\geq 18$ tahun dan memiliki hasil pemeriksaan MODS, pewarnaan ZN, dan GeneXpert. Analisis data menggunakan Uji Cochran's Q dan uji lanjut dengan Uji McNemar. Sebanyak 135 subjek penelitian memenuhi kriteria inklusi dan didapatkan positivitas deteksi M. tuberculosis menggunakan MODS, pewarnaan ZN, dan GeneXpert berturutturut adalah 46,7\%; 20,0\%; dan 37,8\%. Nilai positivitas antara ketiga metode tersebut secara statistik berbeda bermakna dengan nilai $\mathrm{p}<0,05$. Sensitivitas dan spesifisitas GeneXpert dibanding dengan MODS berturut-turut mencapai $68,3 \%$ dan $88,9 \%$, sedangkan sensitivitas pewarnaan ZN sebesar 34,9\% dan spesifisitas $93.1 \%$. Berdasar atas nilai positivitas dan sensitivitas, hasil penelitian ini menunjukkan bahwa metode MODS masih merupakan metode diagnostik terbaik untuk meningitis TB.
\end{abstract}

Kata kunci: Diagnosis, GeneXpert, meningitis tuberkulosis, MODS, pewarnaan Ziehl- Neelsen

\section{Comparison of Positivity Rate of MODS, Ziehl-Neelsen Staining, and GeneXpert Methods in M. tuberculosis Detection among Tuberculous Meningitis Patients}

Abstract

One of the problems in the diagnosis of tuberculous meningitis (TBM) is the low positivity rate of the diagnostic methods. Various methods have been developed, starting from culture MODS (microscopic observation drug susceptibility) to Ziehl-Neelsen (ZN) staining and to GeneXpert. This study was conducted to determine the best diagnostic method to detect $M$. tuberculosis based on its positivity rate. This cross-sectional analytic observational study was conducted on TBM cohort of the ReDEFINe study in Dr. Hasan Sadikin General Hospital. Data were collected from the case reports of TBM inpatients during the period of July 2014-June 2016. Patients $\geq 18$ years who had complete result from MODS, ZN staining, and GeneXpert were included. Data were analyzed using Cochran's Q test and post-hoc analysis using McNemar test. In total, 135 subjects were included in this study. The positivity rates of $M$. tuberculosis detection using MODS, ZN staining, and GeneXpert were $46.7 \%, 20.0 \%$, and $37.8 \%$, respectively. The positivity rate differences among the three diagnostic methods were statistically significant with a p-value of $<0.05$. The sensitivity and specificity of GeneXpert compared to those of MODS were $68.3 \%$ and $88.9 \%$,respectively. Meanwhile the sensitivity and specificity of ZN staining were $34.9 \%$ and $93.1 \%$, respectively. Based on the positivity rate and sensitivity, the results of this study indicates that the MODS method is still the best diagnostic method for TB meningitis.

Key words: Diagnosis, GeneXpert, MODS, tuberculous meningitis, ziehl-neelsen Staining

Korespondensi: Yunia Sribudiani, MSc., PhD, Departemen Ilmu Kedokteran Dasar Fakultas Kedokteran Universitas Padjadjaran Gedung C 2, Jalan Sumedang KM 21, Jatinangor Sumedang, Telepon:+6222-7796373, Email: y.sribudiani@unpad.ac.id 


\section{Pendahuluan}

Angka kejadian tuberkulosis (TB) di dunia masih terbilang sangat tinggi dan menjadi masalah kesehatan yang cukup serius. Berdasar atas data yang didapatkan dari WHO, 58\% kasus TB terjadi di Asia Tenggara dan Pasifik Barat, dan kebanyakan kasus TB terjadi di negara berkembang. Tiga negara dengan kasus TB terbanyak adalah India, China, dan Indonesia, masing-masing menyumbang $23 \%, 10 \%$, dan $10 \%$ dari seluruh kasus TB di dunia. ${ }^{1}$ Tuberkulosis berdasar atas lokasinya dapat dibagi menjadi dua, yaitu tuberkulosis paru dan tuberkulosis ekstraparu. ${ }^{2}$ Tuberkulosis ekstraparu adalah TB yang menyerang organ lain selain paru, seperti sistem saraf pusat (SSP). Sebanyak 1\% kasus TB yang terjadi di dunia adalah tuberkulosis SSP. $^{3}$ Jenis tuberkulosis SSP yang paling berat adalah meningitis TB. ${ }^{4}$ Walaupun sudah terdapat terapi antituberkulosis modern, angka kematian pasien meningitis TB masih tinggi sekitar 20$50 \%$ dan pasien yang bertahan hidup umumnya mempunyai gejala sisa (sequelae) neurologis. ${ }^{5}$

Metode konvensional pada pemeriksaan bakteriologis sekaligus baku emas diagnosis penyakit TB adalah dengan kultur bakteri dan pewarnaan bakteri tahan asam (BTA). ${ }^{3}$ Namun, kegunaan pada kedua metode ini pada pasien meningitis TB masih terbilang cukup rendah. Hal ini disebabkan antara lain karena konsentrasi bakteri M. tuberculosis pada cairan serebrospinal rendah. ${ }^{4}$ Selain itu, kultur bakteri juga kurang sensitif dan membutuhkan waktu sekurang-kurangnya dua minggu untuk dapat memberikan hasil. ${ }^{6}$ Saat ini telah dikembangkan berbagai metode untuk melakukan diagnosis TB, mulai dari modifikasi kultur bakteri (MGIT, MODS), modifikasi pewarnaan (modified Ziehl-Neelsen, Auramine) hingga pemeriksaan berbasis amplifikasi DNA menggunakan metode polymerase chain reaction (PCR) seperti metode Xpert MTB/RIF (GeneXpert). ${ }^{6}$

Kultur mycobacterial observation drug susceptibility (MODS) adalah modifikasi medium cair yang menggabungkan teknik identifikasi bakteri M. tuberculosis dengan drug susceptibility testing (DST). ${ }^{7,8}$ MODS memiliki sensitivitas lebih tinggi dibanding dengan medium solid, mencapai 65\% dengan spesifisitas 98-100\% dan membutuhkan waktu yang cenderung lebih singkat sekitar 6 hari hingga 4 minggu untuk memberikan hasil. Namun, hasil negatifnya tidak dapat langsung digunakan untuk eksklusi diagnosis meningitis TB. ${ }^{7-9}$ Pemeriksaan GeneXpert merupakan sebuah metode real- time PCR yang dapat mendeteksi M. tuberculosis sekaligus melakukan tes resistensi rifampisin (RIF). ${ }^{6}$ GeneXpert memiliki beberapa kelebihan dibanding dengan PCR konvensional, yaitu dapat digunakan di luar lingkungan laboratorium karena menggunakan sistem closed-cartridge based dan tidak harus dilakukan oleh pengguna yang memiliki keahlian khusus. ${ }^{9}$

Sejak bulan Desember tahun 2010, WHO merekomendasikan penggunaan GeneXpert sebagai alat diagnosis awal pada pasien MDRTB dan pasien TB yang mengidap penyakit HIV. GeneXpert juga dapat digunakan pada pasien yang memiliki hasil negatif saat pemeriksaan kultur bakteri atau pewarnaan Ziehl-Neelsen. ${ }^{10}$ GeneXpert sudah tersedia di berbagai negara di dunia termasuk di Indonesia dan lebih banyak digunakan pada pasien TB paru. ${ }^{11}$ Pada bulan Oktober 2013, WHO membuat kebijakan baru bahwa pemeriksaan GeneXpert direkomendasikan untuk mendiagnosis TB paru, TB pada anak, TB ekstraparu, dan juga resistensi rifampisin. ${ }^{12}$ Akan tetapi, keberhasilan GeneXpert dalam mendeteksi bakteri TB pada pasien meningitis TB akan sangat bergantung pada kualitas DNA yang diisolasi dari sampel cairan serebrospinal.

Tujuan penelitian ini adalah membandingkan nilai positivitas metode kultur MODS, pewarnaan Ziehl-Neelsen, dan GeneXpert dalam mendeteksi bakteri M. tuberculosis pada pasien meningitis TB untuk membantu diagnosis dengan lebih cepat dan akurat.

\section{Metode}

Penelitian ini adalah penelitian observasional analitik dengan rancangan potong lintang. Data pada penelitian ini merupakan data penelitian kohort dan ReDEFINe meningitis TB di RSUP Dr. Hasan Sadikin Bandung port form pasien dengan diagnosis meningitis TB yang dirawat inap di bangsal neurologi Rumah Sakit Dr. Hasan Sadikin pada periode Juli 2014-Juni 2016. Pengambilan dan pengolahan data penelitian dilakukan pada bulan September-November 2016.

Kriteria inklusi pada penelitian ini adalah usia $\geq 18$ tahun pada saat pertama masuk, belum mendapatkan obat antituberculosis (OAT), dan memiliki hasil pemeriksaan mikrobiologis lengkap (kultur MODS, pewarnaan ZiehlNeelsen, dan GeneXpert) menggunakan bahan pemeriksaan cairan serebrospinal. Pewarnaan Ziehl-Neelsen (Pewarnaan ZN) dikerjakan hanya satu kali pada setiap sampel cairan serebrospinal 
N. A. Paramitha dkk.: Perbandingan Positivitas Metode MODS, Pewarnaan ZN, dan GeneXpert untuk Mendeteksi M. tuberculosis pada Pasien Meningitis TB

pasien. Kriteria eksklusi pada penelitian ini adalah data case report form pasien yang tidak lengkap. Penentuan sampel pada penelitian ini menggunakan metode total sampling dengan besar sampel minimum sebanyak 62 orang dan seluruh subjek yang memenuhi kriteria inklusi dimasukkan ke dalam penelitian. Persetujuan etik penelitian telah diperoleh dari Komite Etik Penelitian Kesehatan Fakultas Kedokteran Universitas Padjadjaran dengan Nomor: 67/ UN6.C1.3.2/KEPK/PN/2016 pada tanggal 29 Agustus 2016. Data pada penelitian ini disajikan menggunakan Microsoft Excel 2010. Data kemudian dianalisis menggunakan Uji Cochran's $\mathrm{Q}$ dan analisis post hoc (uji lanjut) menggunakan Uji McNemar. Hasil analisis statistik disimpulkan sebagai signifikan jika nilai $\mathrm{p}<0,05$.

\section{Hasil}

Berdasar atas data yang diperoleh dari case report form terdapat 185 pasien dengan diagnosis meningitis TB yang dirawat inap di bangsal neurologi RSUP Dr. Hasan Sadikin pada periode Juli 2014-Juni 2016. Sebanyak 50 pasien dieksklusi dari penelitian karena berusia di bawah 18 tahun $(\mathrm{n}=17)$ dan tidak memiliki pemeriksaan mikrobiologis lengkap $(n=33)$ sehingga didapatkan subjek penelitian sebanyak 135 pasien. Karakteristik subjek penelitian berdasar atas usia, jenis kelamin, dan keluhan utama dapat dilihat pada Tabel 1. Dari seluruh subjek penelitian, 62,2\% adalah laki-laki dan kebanyakan pasien $(75,6 \%)$ datang dengan keluhan utama berupa penurunan kesadaran.

Pengambilan cairan serebrospinal dengan
Tabel 1 Karakteristik Subjek Penelitian $(n=135)$

\begin{tabular}{lc}
\hline \multicolumn{1}{c}{ Karakteristik } & \multicolumn{1}{c}{$\begin{array}{c}\text { Jumlah } \\
\text { n (\%) }\end{array}$} \\
\hline $\begin{array}{l}\text { Usia dalam tahun-median } \\
\text { (rentang) }\end{array}$ & $31(18-80)$ \\
Jenis kelamin & \\
$\quad$ Laki-laki & $84(62,2)$ \\
$\quad$ Perempuan & $51(37,8)$ \\
Keluhan utama & $102(75,6)$ \\
$\quad \begin{array}{l}\text { Penurunan kesadaran } \\
\text { Sakit kepala berat } \\
\text { Gangguan motorik atau } \\
\text { persarafan }\end{array}$ & $25(18,5)$ \\
\hline
\end{tabular}

pungsi lumbal dilakukan pada seluruh subjek penelitian untuk dilaksanakan pemeriksaan diagnostik bakteriologis, yaitu kultur MODS, pewarnaan Ziehl-Neelsen, dan GeneXpert (Tabel 2). Berdasar atas ketiga pemeriksaan bakteriologis yang dilakukan, didapatkan bahwa angka positivitas deteksi bakteri $M$. tuberculosis menggunakan metode kultur MODS, pewarnaan Ziehl-Neelsen, dan GeneXpert secara berturutturut adalah 46,7\%; 20,0\%; dan 37,8\%.

Analisis data pada penelitian ini dilakukan menggunakan Uji Cochran's Q. Uji ini dilakukan untuk melihat apakah terdapat perbedaan statistik yang signifikan antara ketiga metode yang digunakan pada penelitian ini. Hasil uji Cochran's Q menunjukkan perbedaan statistik yang signifikan antara kultur MODS, pewarnaan Ziehl-Neelsen, dan GeneXpert dalam mendeteksi

Tabel 2 Hasil Deteksi M. tuberculosis dengan Kultur MODS, Pewarnaan Ziehl-Neelsen, dan GeneXpert pada Meningitis TB

\begin{tabular}{lcccc}
\hline \multirow{2}{*}{ Metode } & \multicolumn{2}{c}{ Deteksi M. tuberculosis } & \multirow{2}{*}{ Total } & Nilai-p* \\
\cline { 2 - 3 } & Positif (+) & Negatif (-) & & \\
\hline Kultur MODS & 63 & 72 & 135 & \\
$\quad$ Jumlah & 46,7 & 53,3 & 100 & \\
$\quad \%$ & & & & \\
$\begin{array}{l}\text { GeneXpert } \\
\quad \text { Jumlah }\end{array}$ & 51 & 84 & 135 & $<0,001$ \\
$\quad \%$ & 37,8 & 62,2 & 100 & \\
Pewarnaan ZN & & & & \\
$\quad$ Jumlah & 27 & 108 & 135 & \\
$\quad \%$ & 20,0 & 80,0 & 100 & \\
\hline
\end{tabular}

*Uji Cochran's Q 
N. A. Paramitha dkk.: Perbandingan Positivitas Metode MODS, Pewarnaan ZN, dan GeneXpert untuk Mendeteksi M. tuberculosis pada Pasien Meningitis TB

Tabel 3 Perbandingan Hasil Deteksi M. tuberculosis antara Pewarnaan ZN dan Kultur MODS pada Meningitis TB

\begin{tabular}{|c|c|c|c|c|c|c|}
\hline \multirow[b]{2}{*}{ Pewarnaan ZN } & \multicolumn{2}{|c|}{ Kultur MODS } & \multirow[b]{2}{*}{ Total } & \multirow[b]{2}{*}{ Nilai p } & \multirow{2}{*}{$\begin{array}{c}\text { Sensitivitas } \\
(\%)\end{array}$} & \multirow{2}{*}{$\begin{array}{c}\text { Spesifisitas } \\
\text { (\%) }\end{array}$} \\
\hline & $\begin{array}{c}\text { Positif } \\
(+)\end{array}$ & $\begin{array}{c}\text { Negatif } \\
(-)\end{array}$ & & & & \\
\hline Positif (+) & 22 & 5 & 27 & & & \\
\hline Negatif (-) & 41 & 67 & 108 & $<0,001$ & 34,9 & 93,1 \\
\hline Total & 63 & 72 & 135 & & & \\
\hline
\end{tabular}

Tabel 4 Perbandingan Hasil Deteksi M. tuberculosis antara GeneXpert dan Kultur MODS pada Meningitis TB

\begin{tabular}{|c|c|c|c|c|c|c|}
\hline \multirow{2}{*}{ GeneXpert } & \multicolumn{2}{|c|}{ Kultur MODS } & \multirow{2}{*}{ Total } & \multirow{2}{*}{ Nilai $p$} & \multirow{2}{*}{$\begin{array}{c}\text { Sensitivitas } \\
\text { (\%) }\end{array}$} & \multirow{2}{*}{$\begin{array}{c}\text { Spesifisitas } \\
\text { (\%) }\end{array}$} \\
\hline & Positif (+) & Negatif (-) & & & & \\
\hline Positif (+) & 43 & 8 & 51 & & & \\
\hline Negatif $(-)$ & 20 & 64 & 84 & 0,038 & 68,3 & 88,9 \\
\hline Total & 63 & 72 & 135 & & & \\
\hline
\end{tabular}

M. tuberculosis pada pasien meningitis TB ( $\mathrm{p}<0,001$; Tabel 2).

Analisis post hoc (uji lanjut) kemudian dilakukan menggunakan Uji McNemar. Analisis ini bertujuan melihat kelompok pasangan mana yang memiliki perbedaan paling signifikan antara pewarnaan Ziehl-Neelsen dan kultur MODS (Tabel 3), GeneXpert dengan kultur MODS (Tabel 4), dan pewarnaan Ziehl-Neelsen dengan GeneXpert (Tabel 5). Berdasar atas hasil analisis yang dilakukan terdapat perbedaan statistikyang signifikan antara ketiga kelompok pasangan.

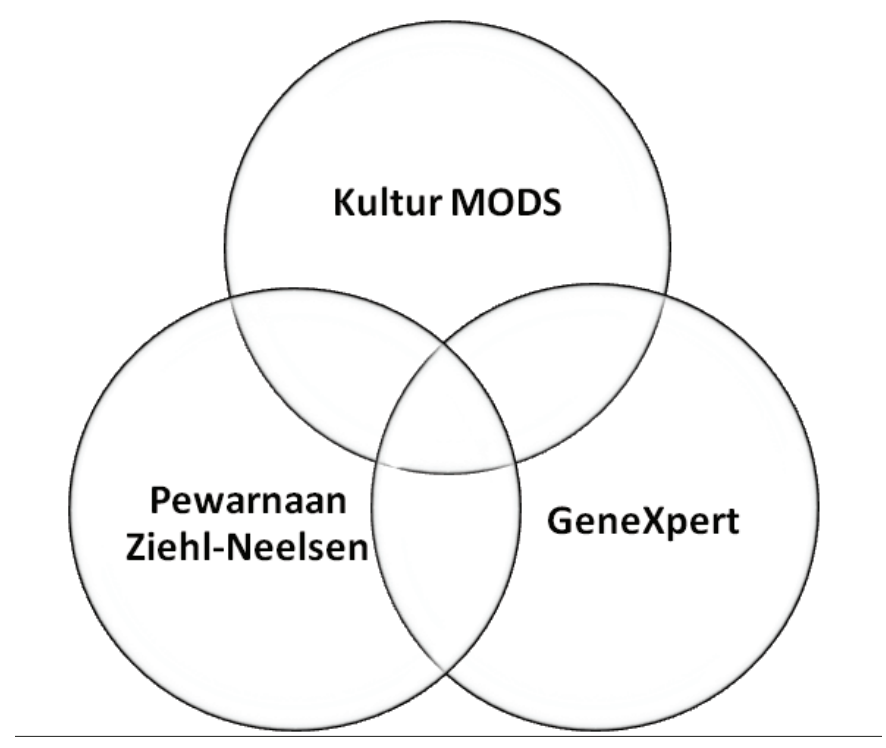

Gambar Perbandingan Hasil Deteksi M. tuberculosis dengan Kultur MODS, Pewarnaan ZN, dan GeneXpert pada Meningitis TB

Sebanyak 63 (46,7\%), 51 (37,8\%) dan 27 (20\%) dari total sampel 135 berhasil diidetifikasi sebagai MTB positif secara berturut-turut oleh metode MODS, GeneXpert dan pewarnaan ZN. Sebanyak 63 sampel positif hasil pemeriksaan MODS dapat dikonfirmasi sebanyak 43 sampel oleh metode GeneXpert dan 22 sampel oleh metode ZN. 
N. A. Paramitha dkk.: Perbandingan Positivitas Metode MODS, Pewarnaan ZN, dan GeneXpert untuk Mendeteksi M. tuberculosis pada Pasien Meningitis TB

Tabel 5 Perbandingan Hasil Deteksi M. tuberculosis antara Pewarnaan ZN dan GeneXpert pada Meningitis TB

\begin{tabular}{lcccc}
\hline \multirow{2}{*}{ Pewarnaan Ziehl-Neelsen } & \multicolumn{2}{c}{ GeneXpert } & \multirow{2}{*}{ Total } & \multirow{2}{*}{ Nilai p } \\
\cline { 2 - 3 } & Positif (+) & Negatif $(-)$ & & \\
\hline Positif $(+)$ & 24 & 3 & 27 & \\
Negatif $(-)$ & 27 & 81 & 108 & $<0,001$ \\
Total & 51 & 84 & 135 & \\
\hline
\end{tabular}

MODS memiliki nilai positivitas tertinggi dibanding dengan dengan dua metode lainnya, oleh karena itu pada penelitian ini MODS dijadikan sebagai pembanding untuk melihat sesitivitas dan spesifisitas metode pewarnaan ZN dan GeneXpert. Hasil menunjukkan metode GeneXpert dan juga pewarnaan ZN berturutturut memiliki sensitivitas $68,3 \%$ dan $34,9 \%$ dibanding dengan sensitivitas metode MODS. Spesifisitas metode GeneXpert dan pewarnaan ZN berturut-turut $88,9 \%$ dan $93,1 \%$ dibanding dengan spesifisitas metode MODS (Tabel 3 dan 4). Berdasar atas data yang didapatkan dari case report form, sebanyak 60 dari 63 subjek penelitian dengan hasil positif pada kultur MODS mencantumkan waktu yang dibutuhkan untuk mendeteksi bakteri sejak dilakukan pungsi lumbal sampai kultur memberikan hasil positif, yaitu pada rentang waktu 7 hingga 76 hari dengan median 22,5 hari.

Untuk melihat perbandingan yang lebih jelas dari ketiga pemeriksaan, data penelitian ini disajikan dalam bentuk diagram yang dapat menunjukkan perbandingan dan irisan positivitas antara ketiga metode (Gambar).

\section{Pembahasan}

Meningitis tuberkulosis merupakan penyakit yang memiliki tingkat mortalitas yang cukup tinggi. Keterlambatan dalam melakukan suatu diagnosis dapat meningkatkan risiko komplikasi seperti hidrosefalus, infark pembuluh darah otak, kelumpuhan saraf kranial, bahkan kematian. ${ }^{13}$ Baku emas untuk diagnosis meningitis TB adalah deteksi bakteri $M$. tuberculosis dalam cairan serebrospinal, baik menggunakan pewarnaan Ziehl-Neelsen maupun isolasi bakteri dengan kultur. Namun, kedua pemeriksaan bakteriologis tersebut masih memiliki sensitivitas yang rendah. ${ }^{14}$

Diagram pada Gambar telah menunjukkan bahwa dari 135 subjek penelitian, hanya
73 pasien (54,1\%) yang menunjukkan hasil positif saat dilakukan pemeriksaan diagnostik bakteriologis. Hal ini kemungkinan disebabkan oleh konsentrasi bakteri M. tuberculosis dalam cairan serebrospinal. ${ }^{4}$ Diagram tersebut juga menunjukkan bahwa kultur MODS merupakan pemeriksaan dengan kemampuan deteksi $M$. tuberculosis yang paling tinggi $(46,7 \%)$ dibanding dengan dengan kedua pemeriksaan lainnya. Sebuah penelitian tentang TB paru yang dilakukan di Filipina menunjukkan bahwa kultur MODS memiliki positivitas $62,9 \%{ }^{15}$ Penelitian TB paru di Iran menunjukkan bahwa kultur MODS memiliki positivitas $47 \%{ }^{16}$ Hal ini menegaskan bahwa keberhasilan kultur TB bahkan dengan menggunakan spesimen yang berasal dari tempat dengan load bakteri yang banyak seperti sputum juga tidak mencapai $100 \%$ sehingga menjadikan kultur sebagai baku emas yang tidak sempurna.

Dari 73 subjek yang mempunyai hasil pemeriksaan positif, terdapat 19 subjek (26\%) M. tuberculosis hanya dapat dideteksi menggunakan kultur MODS dan menunjukkan hasil negatif pada kedua pemeriksaan lainnya. Selain memiliki kemampuan deteksi bakteri yang paling tinggi, kultur MODS juga memiliki kemampuan untuk melakukan konfirmasi atas kedua pemeriksaan lainnya. Waktu deteksi kultur MODS pada penelitian ini berada pada rentang 7 hingga 76 hari dengan median 22,5 hari. Hasil ini berbeda dengan penelitian di Vietnam yang menyatakan bahwa waktu deteksi M. tuberculosis menggunakan kultur MODS memiliki median 6 hari. Hasil yang berbeda cukup jauh ini mungkin berhubungan dengan positivitas kultur MODS pada penelitian di Vietnam yang lebih tinggi $(64,9 \%)$ dibanding dengan dengan penelitian ini $(46,7 \%)$ dan load bakteri yang lebih banyak pada penelitian di Vietnam sehingga waktu deteksi menjadi lebih cepat.7

Walaupun metode kultur termasuk metode MODS masih memiliki kelemahan karena waktu pengerjaan yang relatif lama, pada penelitian ini metode MODS mempunyai nilai positivitas 
paling tinggi dibanding dengan GeneEXpert dan pewarnaan ZN. Dengan demikian, pada penelitian ini metode MODS dijadikan pembanding untuk melihat sensitivitas dan spesifisitas GeneExpert dan pewarnaan ZN. Pewarnaan Ziehl-Neelsen memiliki sensitivitas $34,9 \%$ dan spesifisitas 93,1\% jika dibanding dengan dengan kultur MODS sebagai baku emas (Tabel 3). Hasil ini menunjukkan sensitivitas pewarnaan ZiehlNeelsen yang lebih tinggi dibanding dengan penelitian yang dilakukan di China yang menyatakan bahwa pewarnaan Ziehl-Neelsen memiliki sensitivitas $22,9 \%$ dibanding dengan kultur. ${ }^{17}$

Pemeriksaan GeneXpert memiliki sensitivitas $68,3 \%$ dan spesifisitas $88,9 \%$ jika dibanding dengan dengan kultur MODS (Tabel 4). Hal ini berbeda dengan hasil penelitian di Vietnam yang mendapatkan bahwa GeneXpert memiliki sensitivitas 59,3\% dan spesifisitas 99,5\%. ${ }^{9}$ Kemungkinan hal ini disebabkan oleh load bakteri pada spesimen yang dikumpulkan di Indonesia lebih rendah bila dibanding dengan dengan yang dikumpulkan di Vietnam. Secara teori, pemeriksaan GeneXpert mempunyai kelebihan bila dibanding dengan kultur MODS dari segi kecepatan diagnosis, karena GeneXpert hanya membutuhkan waktu kurang lebih 2 jam untuk dapat memberikan hasil. ${ }^{12}$

Pada penelitian ini GeneXpert menunjukkan positivitas yang lebih rendah bila dibanding dengan dengan kultur MODS. Penelitian yang dilakukan di Afrika Selatan menunjukkan bahwa proses sentrifugasi cairan serebrospinal dapat meningkatkan ketepatan diagnosis, terutama di daerah dengan angka kejadian TB yang tinggi. ${ }^{18}$ Hasil penelitian GeneXpert di Uganda juga menunjukkan positivitas yang lebih tinggi pada cairan serebrospinal yang disentrifugasi (72\%) dibanding dengan spesimen yang tidak diproses terlebih dahulu (28\%). ${ }^{19}$ Pemeriksaan pada penelitian ini juga menggunakan sampel cairan serebrospinal yang disentrifugasi terlebih dahulu, namun menunjukkan hasil yang lebih rendah dibanding dengan dengan penelitian sebelumnya. Salah satu kemungkinan penyebab positivitas GeneXpert pada penelitian ini rendah karena load bakteri rendah pada sampel yang digunakan. Hasil penelitian di Vietnam bahwa load bakteri dalam cairan serebrospinal yang digunakan untuk pemeriksaan GeneXpert digolongkan dalam kategori rendah $(42,2 \%)$ dan sangat rendah $(49,5 \%){ }^{9}$ Positivitas GeneXpert yang rendah di samping kelebihannya dalam segi waktu pada penelitian ini membuat metode ini belum mampu dipertimbangkan menjadi pengganti kultur sebagai baku emas diagnosis.

Penelitian lanjutan terkait optimasi metode yang telah ada untuk mendapatkan hasil pemeriksaan yang lebih baik perlu dilakukan. Salah satunya adalah optimasi metode isolasi DNA dari cairan serebrospinal agar kualitas dan kuantitas DNA yang dihasilkan optimum dan dapat meningkatkan positivitas metode GeneXpert. Selain itu, dapat juga dilakukan pengembangan metode yang murah dan juga cepat seperti pewarnaan ZN modifikasi untuk mendeteksi bakteri intraseluler. ${ }^{17}$ Dua penelitian tentang pewarnaan ZN modifikasi yang dilakukan di China menunjukkan bahwa metode ini dapat meningkatkan positivitas deteksi $M$. tuberculosis menjadi 100\%, namun hasil penelitian ini belum dikonfirmasi pada setting yang lain. . $^{17,20}$

Simpulan, kultur MODS memiliki positivitas paling tinggi apabila dibanding dengan metode pewarnaan Ziehl-Neelsen dan juga GeneXpert dalam mendeteksi $M$. tuberculosis pada meningitis. Uji sensitivitas dan spesifisitas dengan menggunakan metode MODS sebagai pembanding telah menunjukkan bahwa metode GeneExpert lebih unggul bila dibanding dengan metode pewarnaan ZN. Penggunaan MODS secara simultan dengan GeneExpert dapat meningkatkan positivitas deteksi $M$. tuberculosis sehingga dapat dipertimbangkan dipergunakan sebagai metode penyerta kultur MODS untuk menegakkan diagnosis meningitis TB.

\section{Daftar Pustaka}

1. WHO. Global Tuberculosis Report 2015. Geneva: WHO; 2015.

2. Lee JY. Diagnosis and treatment of extrapulmonary tuberculosis. Tuberc Respir Dis (Seoul). 2015;78(2):47-55.

3. Rock RB, Olin M, Baker CA, Molitor TW, Peterson PK. Central nervous system tuberculosis: pathogenesis and clinical aspects. Clin Microbiol Rev. 2008;21(2):24361.

4. Pasco PM. Diagnostic features of tuberculous meningitis: a cross-sectional study. BMC Res Notes. 2012;5(1):49.

5. Murthy JMK. Tuberculous meningitis: the challenges. Neurol India. 2010;58(5):716.

6. Marais S, Wilkinson RJ. The diagnosis and medical management of tuberculous meningitis in adults. S Afr Med J. 2014; 104(12):895.

7. Caws M, Ha DTM, Torok E, Campbell J, Thu DDA, Chau TTH, dkk. Evaluation of the 
MODS culture technique for the diagnosis of tuberculous meningitis. PLoS One. 2007;2(11):1-11.

8. Zhang L, Feng G, Zhao G. Tuberculous meningitis in Asia. Neurol Asia. 2015;20(1):1-6.

9. Nhu NTQ, Heemskerk D, Thu DDA, Chau TTH, Mai NTH, Nghia HDT, dkk. Evaluation of GeneXpert MTB/RIF for diagnosis of tuberculous meningitis. J Clin Microbiol. 2014;52(1):226-33.

10. Lawn S, Nicol M. Xpert ${ }^{\circledR}$ MTB/RIF assay: development, evaluationandimplementation of a new rapid molecular diagnostic for tuberculosis and rifampicin resistance. Future Microbiol. 2011;6(9):1067-82.

11. Carrol KC, Hobden JA, Miller S, Morse SA, Mietzner TA, Detrick B, dkk. Jawetz melnick $\&$ adelbergs medical microbiology. Edisi ke27. New York: McGraw-Hill Education; 2015. hlm. 309-17.

12. WHO. Xpert MTB/RIF implementation manual technical and operational "howto": practical considerations. Geneva: WHO; 2014.

13. Christensen A-SH, Andersen $\AA \AA B$, Thomsen VØ, Andersen PH, Johansen IS. Tuberculous meningitis in Denmark: a review of 50 cases. BMC Infect Dis. 2011;11(1):1-6.

14. Brancusi F, Farrar J, Heemskerk D. Tuberculous meningitis in adults: a review of a decade of developments focusing on prognostic factors for outcome. Future Microbiol. 2012;7(9):1101-16.
15. Mendoza MT, Cajucom MAM, Itable JR, Zamora RP. Evaluation of the usefulness of the MODS assay for the detection of TB and MDR-TB among PTB suspects in the Philippines. Clin Microbiol. 2015;4(4):1-6.

16. Aminzadeh Z, Fallah F, Manafian B, Baghaei P. Evaluation of MODS culture in the diagnosis of pulmonary tuberculosis. African J Microbiol Res. 2012;6(2):288-91.

17. Chen P, Shi M, Feng G-D, Liu J-Y, Wang B-J, Shi X-D, dkk. A highly efficient Ziehl-Neelsen stain: identifying de novo intracellular Mycobacterium tuberculosis and improving detection of extracellular M. tuberculosis in cerebrospinal fluid. J Clin Microbiol. 2012;50(4):1166-70.

18. Patel VB, Theron G, Lenders L, Matinyena B, Connolly C, Singh R, dkk. Diagnostic accuracy of quantitative PCR (Xpert MTB/RIF) for tuberculous meningitis in a high burden setting: a prospective study. PLoS Med. 2013;10(10):1-13.

19. Bahr NC, Tugume L, Rajasingham R, Kiggundu R, Williams DA, Morawski B, dkk. Improved diagnostic sensitivity for tuberculous meningitis with Xpert MTB/ RIF of centrifuged CSF. Int J Tuberc Lung Dis. 2015;19(10):1209-15.

20. Feng GD, Shi M, Ma L, Chen P, Wang BJ, Zhang M, dkk. Diagnostic accuracy of intracellular Mycobacterium tuberculosis detection for tuberculous meningitis. Am J Respir Crit Care Med. 2014;189(4):475-81. 